\title{
Acute Toxicity and Haematological Studies of Textile Based Industrial Effluent of Pali City on a Freshwater Fish Clarias batrachus (L.)
}

\author{
Surendra Makwana† \\ Department of Zoology, Jai Narain Vyas University, Jodhpur, Rajasthan, India \\ †Corresponding author: Surendra Makwana; skmakwanajod@gmail.com
}

Nat. Env. \& Poll. Tech. Website: www.neptjournal.com

Received: 11-06-2020

Revised: $03-08-2020$

Accepted: 27-08-2020

\section{Key Words:}

Textile effluents

Haematology

Acute toxicity

Clarias batrachus (L.)

\begin{abstract}
The acute toxicity bioassay of textile industrial effluent (TIE) was carried out by the probit analysis method. The 12, 24, 48, 72 and $96 \mathrm{~h} \mathrm{LC50}$ values were obtained as $56.23 \%, 28.84 \%, 22.38 \%$ and $16.59 \%$ respectively. LC50 values were significantly decreased with increase in effluent concentration. The safe value was found to be $32.88 \%$. The experimental fish C.batrachus exhibited stressful behaviour which increased with toxicant concentration. Due to acute toxicity of textile based industrial effluent, experimental fish $C$. batrachus expressed high secretion of mucus, uncoordinated and tailfin movement, surfacing, loss of buoyancy, escaping tendency, hyperactivity, and discolouration of the skin. Mortalities were observed in all treatments except control. The haematological analysis was also carried out in experimental fish C.batrachus exposed to various periods in textile-dyeing effluents. Haematological data were evaluated for parameters such as $\mathrm{Hb}, \mathrm{RBCs}, \mathrm{WBCs}, \mathrm{PCV}, \mathrm{MCH}$, and $\mathrm{MCHC}$ of the test species. The alterations of these parameters have been discussed. So it can be concluded that the TIE is toxic to fishes and aquatic organisms.
\end{abstract}

\section{INTRODUCTION}

Water quality of aquatic habitat is altered due to anthropogenic activity (Makwana 2020a). Besides this, the textile industryand its effluents are one of the main sources of severe pollution problems worldwide. The important pollutants in textile wastewater are mainly organics, dye and toxicants. The wastewater contains a different variety of chemicals from the various stages of operations which include printing, scouring, bleaching and dyeing (Deepali \& Gangwar 2010). Berardi et al. (2019) have described the different classes of dyes and pigments used in textile processes like dyeing and printing.

The printing and dyeing textile industries cover a major portion of the industrial section in Pali city. The textile effluents discharged through these industries are toxic (Satish et al. 2008). Improperly treated wastewater from the textile and dyeing industries of Pali is affecting groundwater quality and its surrounding areas due to the discharge of wastewater.

Textile effluents discharged in Bandi River, Pali city are highly toxic and alter the quality of river water and severely affect aquatic organisms (Makwana 2020b). It is observed in the study that the $\mathrm{pH}$ of river water is more than the permissible limit while most of the parameters like BOD and total hardness are much higher. TDS, chloride and sulphate concentrations are more in the outlet sample than the inlet sample. The main pollutants in the wastewater released from each step in the wet process of textiles as predicted by Holkar et al. (2016). According to Yaseen \& Scholz (2016), the textile dye effluents are dark in colour and have high $\mathrm{pH}$, suspended solids, chemical oxygen demand and biochemical oxygen demand.

Taiwo et al. (2018) suggested that the study of textile effluent samples from an industry placed at Oba Akran Road (Ikeja) reported some form of pre-treatment is being embarked upon within the premises before releasing into the environment. Textile wastewater can alter the quality of water and create several hazardous and health problems like allergies, dermatitis, skin problems and cancers in humans (Sarvajith et al. 2018).Due to the widespread use of textile dyes, these toxic contaminants can be present in the environment and store biologically throughout the food chain in aquatic organisms (Hossain et al. 2018).

Bioassay is a test to estimate the relative strength of a chemical by comparing its effects on animals with that of standard preparations (Rand et al. 1985). Several studies have been carried out on the effect of different industrial effluents on fish (Maruthi\& Rao 2001). Relative toxicity of bleaching, dyeing and printing textile mill effluents to the freshwater fish Oreochromis mossambicushave been studied by Haniffa et al. (1991). 
Effects of dairy effluent on the behaviour of Cyprinus carpio were studied (Amutha et al.1999). Nagarajan \& Ramesh (2001) noticed the impact of Sago effluent on the freshwater fish Catla catla. Nagarajan \& Shasikumar (2002) observed similar findings on the fish Labeo rohita exposed to sago industry effluent. Shanthi (2003) has reported the effects of the tannery effluent on the freshwater fish Catlacatla. Nagarajan \& Boopathi Raja (2004) have noticed the toxic impact of dyeing effluent to the fish Catlacatla. Similar observations have been made by Nagarajan \& Suresh (2005) in the fish Cirrhinus mrigala in sago effluent. Nagarajan \&Aruna(2006) have studied the impact of distillery effluent on the fish Labeo rohita.

Many bioassays have been carried out to monitor and assess the toxicity of wastewater from domestic and various industries (Hader 2018). Acute toxicity bioassay of pretilachlor (herbicide) by probit analysis method in the fish Clarias batrachus was investigated by Soni et al. (2018). Arya et al. (2018) evaluated the $96 \mathrm{hr}$ LC50 value of lead acetate for the fish Oreochromis mossambicus. The acute toxicity test was performed according to the standard methods of APHA and the values were calculated by probit analysis.

Haematological parameters were evaluated for the fish Oreochromis mossambicus exposedto the textile effluent by Amte et al. (2013). Srivastav \& Dayalanand (2015) studied haematological parameters of a freshwater catfish Heteropneustes fossilis exposed to dye. Haematological parameters are very important in determining the health and physiological status of fishes (Clauss et al. 2008, Adeyemo et al. 2009).

The present investigation was designed to study the acute toxicity of textile effluent to the fish Clarias batrachus and effect of the effluent on its behavioural response.

\section{MATERIALS AND METHODS}

\section{Collection and Acclimatization of the Experimental Fish}

Clarias batrachus fish were collected locally and transported to the laboratory in large aerated polythene bags containing water from the collection site. Healthy fish were placed in a large glass aquarium. Before the experiment, the tanks were washed and fish were treated with $0.1 \%$ of $\mathrm{KMnO}_{4}$ solution to protect from any dermal infection.

The fish were acclimatized in laboratory conditions for 2 weeks before they were used in the bioassay tests. Water was changed every 48 hours to remove faecal matter and waste metabolite of fish and enhance oxygen content in the water. During acclimatization, the fish were fed with the protein diet. The fish were starved for 24 hours before the experiment. The method employed in this experiment is based on the recommended method for the test of acute toxicity of pollutants to fish described by APHA (2000).

\section{Acute Toxicity Bioassay and Statistical Analysis of Data}

Six graded concentrations of textile effluents were used as $0 \%$ (control), $10 \%, 30 \%, 50 \%$ and $70 \%$. Control did not contain the textile effluent. Ten juvenile fish were used and estimated for mortality rate after 24, 48, 72 and 96 hours. Dead fish were removed immediately to prevent water pollution. The 24, 48, 72 and 96hr lethal median concentration (LC50) was determined as a probit analysis using the probit mortality versus the log concentration. The LC50 value was extrapolated from probit 5 to the log concentration. The antilog values provide the LC50 in \%. Percentage mortality probit values were taken from Finney's Table (Finney 1971)
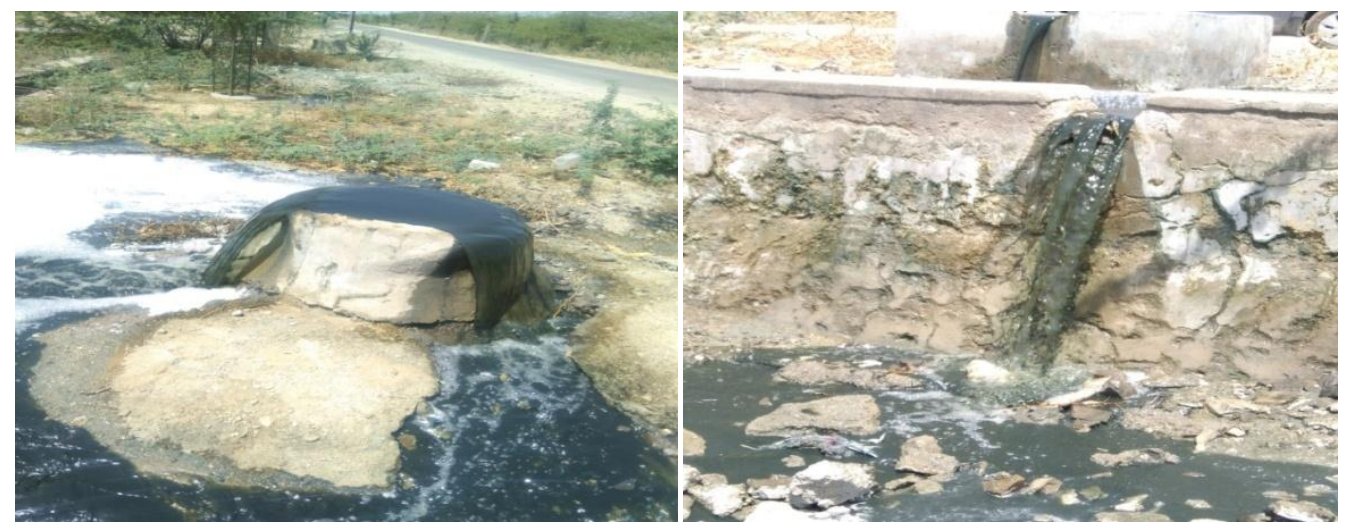

Fig. 1: Flow of textile effluents into Bandi River near Pali industrial area. 
Mortality data were recorded after 24, 48, 72 and $96 \mathrm{~h}$ to get LC50 of respective intervals. The toxicity of textile effluent on morphological and behavioural parameters was recorded. Control and textile effluent treated group of fish were consistently monitored in intervals to get the frequency. The data were recorded as suggested by Gupta \& Dua (2010).

\section{Haematological Parameters}

The haematological indices of mean cell haemoglobin concentration (MCHC), mean cell haemoglobin $(\mathrm{MCH})$ and mean cell volume (MCV) were calculated using the total red blood cell count (RBC), haemoglobin concentration $(\mathrm{Hb})$, and haematocrit (HCT) as given below.

Mean corpuscular volume $(\mathrm{MCV})=\mathrm{HCT} / \mathrm{RBC}$

Mean corpuscular haemoglobin $(\mathrm{MCH})=[\mathrm{Hb} \times 10] / \mathrm{RBC}$

Mean corpuscular haemoglobin concentration (MCHC)

$=[\mathrm{Hb} \times 10] / \mathrm{HCT} \times 100$

\section{RESULTS AND DISCUSSION}

\section{Lethal Toxicity Test}

The LC50 values with $95 \%$ confidence limits of different concentrations of the textile effluent were determined and represented in Table 6. Significant differences in $(\mathrm{p}<0.05)$ in LC50 values were observed for different times of exposures. As the exposure time increases the median lethal concentration (LC50) decreases.

Flow of textile effluent directly into bandi river near Pali industrial area is shown in Fig1. Exposure to C. $b a$ trachus with different concentrations of textile industrial effluent (TIE) showed a varying degree of mortality with a wide range of concentrations (Table 1). The percentage of mortality was significantly increased with the increase in the concentration of the toxicant as well as the duration of the experiment that is given in Tables 1-5 and Figs. 1-5.

Table 1: Mortality rate of Clarias batrachus exposed to different concentrations of the effluent.

\begin{tabular}{|c|c|c|c|c|c|c|c|c|c|}
\hline \multicolumn{10}{|l|}{ Mortality Percentage } \\
\hline \multirow[t]{2}{*}{ Concentration \% ( v/v) } & \multirow[t]{2}{*}{ No. of fish } & \multicolumn{2}{|c|}{$24 \mathrm{hrs}$} & \multicolumn{2}{|c|}{$48 \mathrm{hrs}$} & \multicolumn{2}{|c|}{$72 \mathrm{hrs}$} & \multicolumn{2}{|c|}{$96 \mathrm{hrs}$} \\
\hline & & M & M \% & M & M \% & M & M \% & M & M\% \\
\hline Control & 10 & 0 & 0 & 0 & 0 & 0 & 0 & 0 & 0 \\
\hline $10 \%$ & 10 & 0 & 0 & 1 & 10 & 2 & 20 & 3 & 30 \\
\hline $30 \%$ & 10 & 2 & 20 & 3 & 30 & 5 & 50 & 7 & 70 \\
\hline $50 \%$ & 10 & 3 & 30 & 5 & 50 & 7 & 70 & 9 & 90 \\
\hline $70 \%$ & 10 & 6 & 60 & 10 & 100 & - & - & - & - \\
\hline
\end{tabular}

Table 2: Log concentrations and probit values when exposed to textile effluent after $24 \mathrm{~h}$.

\begin{tabular}{|llllll|}
\hline S. No. & Conc. $\%(\mathrm{v} / \mathrm{v}) 24 \mathrm{hrs}$ & Log Conc. & No. of Fish & \multicolumn{2}{l|}{ 24 hrs } \\
\hline & & & 10 & 0 & Mortality \% \\
2 & Control & 0 & 10 & 0 & 0 \\
3 & $10 \%$ & 1.0000 & 10 & 20 & 4.1 \\
4 & $30 \%$ & 1.4771 & 10 & 30 & 4.48 \\
5 & $50 \%$ & 1.6989 & 10 & 60 & 5.25 \\
\hline
\end{tabular}

Table 3: Log concentrations and probit values when the fish exposed to textile effluent after $48 \mathrm{~h}$.

\begin{tabular}{|llllll|}
\hline S. No. & Conc. $\%(\mathrm{v} / \mathrm{v}) 48 \mathrm{hrs}$ & Log Conc. & No. of Fish & Mortality $\%$ & Probit \\
\hline 1 & & & 10 & 0 & 0 \\
2 & Control & 0 & 10 & 10 & 3.72 \\
3 & $10 \%$ & 1.0000 & 10 & 30 & 4.48 \\
4 & $30 \%$ & 1.4771 & 10 & 50 & 5 \\
5 & $50 \%$ & 1.6989 & 10 & 100 & 7.37 \\
\hline
\end{tabular}


Table 4: Log concentrations and probit values when the fish exposed to textile effluent after $72 \mathrm{~h}$.

\begin{tabular}{|llllll|}
\hline S. No. & Conc. \% (v/v) $72 \mathrm{hrs}$ & Log Conc. & No. of Fish & Mortality \% \\
\cline { 3 - 6 } & & & & 0 & 0 \\
2 & Control & 0 & 10 & 20 & 4.1 \\
3 & $10 \%$ & 1.0000 & 10 & 50 & 5 \\
4 & $30 \%$ & 1.4771 & 10 & 70 & 5.52 \\
5 & $50 \%$ & 1.6989 & 10 & 100 & 7.37 \\
\hline
\end{tabular}

Table 5: Log concentrations and probit values when the fish exposed to textile effluent after $96 \mathrm{~h}$.

\begin{tabular}{|c|c|c|c|c|c|}
\hline \multirow[t]{2}{*}{ S. No. } & \multirow[t]{2}{*}{ Conc. \% (v/v) 96 hrs } & \multirow[t]{2}{*}{ Log Conc. } & \multirow[t]{2}{*}{ No. of Fish } & \multicolumn{2}{|l|}{$96 \mathrm{hrs}$} \\
\hline & & & & Mortality $\%$ & Probit \\
\hline 1 & Control & 0 & 10 & 0 & 0 \\
\hline 2 & $10 \%$ & 1.0000 & 10 & 30 & 4.48 \\
\hline 3 & $30 \%$ & 1.4771 & 10 & 70 & 5.52 \\
\hline 4 & $50 \%$ & 1.6989 & 10 & 90 & 6.28 \\
\hline 5 & $70 \%$ & 1.8450 & 10 & 100 & 7.37 \\
\hline
\end{tabular}

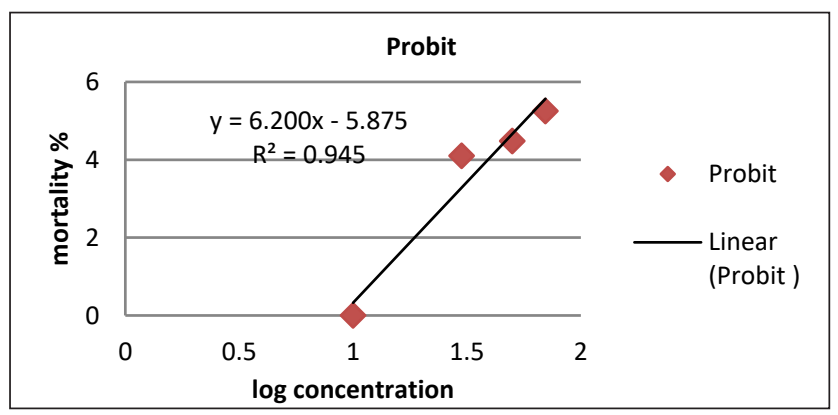

Fig. 2: Linear regression curve of log concentration and mortality response of C.batrachus after $24 \mathrm{hrs}$. exposure to textile effluent.

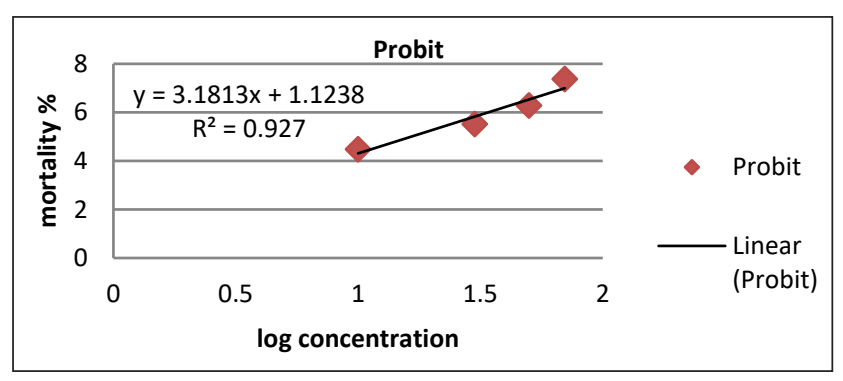

Fig. 4: Linear regression curve of log concentration and mortality response of C.batrachus after $72 \mathrm{hrs}$ exposure to textile effluent.

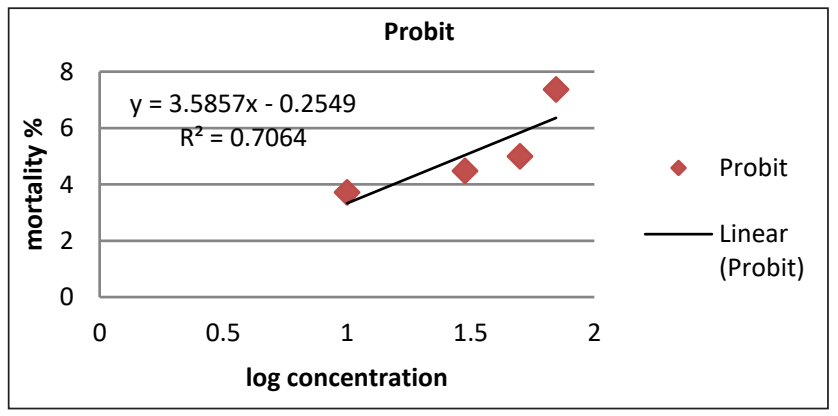

Fig. 3: Linear regression curve of log concentration and mortality response of C.batrachus after 48 hrs exposure to textile effluent.

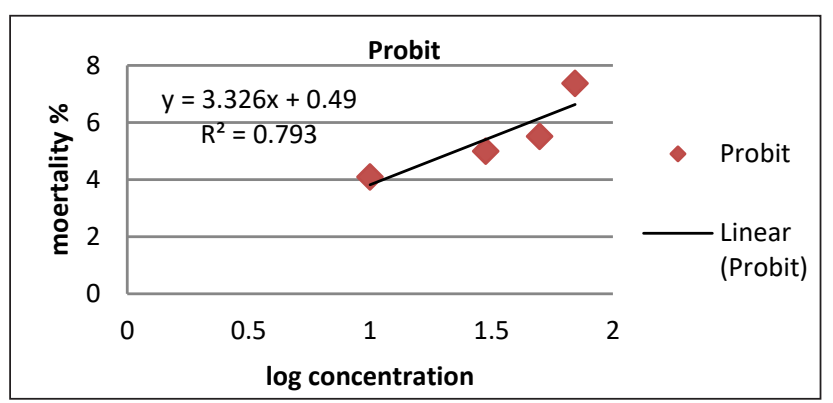

Fig. 5: Linear regression curve of log concentration and mortality

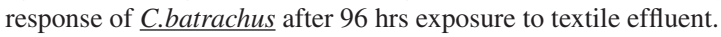

Table 6: Lethal concentrations of textile effluent at various exposure times for C. batrachus.

\begin{tabular}{|lllllll|}
\hline S.No. & Time period & LC50 \% & Regression line/slope & Coefficients & \multicolumn{2}{l}{ 95\% Confidence Interval } \\
\cline { 5 - 6 } & & & & & Lower Bound & Upper Bound \\
\hline 1. & $24 \mathrm{~h}$ & 56.23 & $\mathrm{y}=6.200 \mathrm{x}-5.875$ & $6.1992 \pm 1.050$ & 1.67725 & 10.72132 \\
3. & $48 \mathrm{~h}$ & 28.84 & $\mathrm{y}=3.585 \mathrm{x}-0.254$ & $3.5853 \pm 1.6343$ & -3.4468 & 10.6176 \\
4. & $72 \mathrm{~h}$ & 22.38 & $\mathrm{y}=3.181 \mathrm{x}+1.123$ & $3.3263 \pm 1.2012$ & -1.8422 & 8.4950 \\
\hline
\end{tabular}

Lethal concentration values in rows with different letters significantly differ at $\mathrm{p}<0.05$. 
No mortality was found in the control group of fish. In the experimental group of fish, results were noted as $10 \%$ to $70 \%$ mortality during the experiment at $24,48,72$ and 96 hours (Table 6). The LC50 values were found to be $56.23 \%$, $28.84 \%, 22.38 \%, 16.59 \%$ at $24,48,72$ and 96 hours respectively as summarised in Table 6 . From the above results, it was observed that the toxic effect of effluent is very high to Clarias batrachus and it was considered to be highly toxic wastewater to the fishes.

Safe concentration for toxic textile effluent to fish Clarias batrachus was calculated by the method described by Hart et al. (1945). Safe concentration was found to be $32.88 \%$ (Table 6). The lethal toxicity test reported that fish in the control tank survived whereas mortalities were recorded in all treatment concentrations. Graphs were plotted between $\log$ concentration (mortality \%) and probit value at different internal exposure 24, 48, 72 and 96 hrs respectively (Figs.1, 2, 3 and 4).Mortality increased with increasing concentration of the toxicant in water. A similar observation of different fish species exposed to different levels of toxicants is reported by other workers (Agbon et al. 2002, Omoregie et al. 2009, Umar et al. 2010).

The variation in acute toxicity may be due to alteration in water quality and test species. Variability in acute toxicity even in a single species and single toxicant depending on the size, age, experimental species and factors (Farah et al. 2004). The existing physiological parameters of water were reported by Eaton \& Gilbert (2008). It is evident from the results that the high concentration of textile effluent with chemical dye, toxic elements and heavy metals has a direct effect on the LC50 values of the respective fish.

Sreelekshmy et al. (2016) studied acute toxicity of industrial effluent on catfish and reported that mills effluents are the main pollutants in the aquatic environment and affect the aquatic organisms especially fishes. Mortality rate increases with increasing toxicity level of textile effluent. LC 50 values were declined by increasing concentration of textile effluent and time exposure.

\section{Behavioural and Morphological Alterations}

The behavioural responses of the test fish to the toxicant at different concentrations at the period of $96 \mathrm{~h}$ (Table 7) indicated high secretion of mucus, uncoordinated movement, restlessness, tailfin movement, loss of balance surfacing, loss of buoyancy, escaping tendency, hyperactivity and discolouration of the skin. Mortalities were observed in all the treatments except control. The fish exhibits stressful behaviour which increased with the toxicant concentration. Similar behaviour of $C$. gariepinuswas observed by Fafioye et al. (2001) and of $C$. punctatusby Rahman et al. (2002) with the effluent.

Behaviour is an organism-level effect defined as the action, reaction or functioning of a system under a set of specific circumstances. We rationalize that a greater understanding of behavioural responses in effect to chemical stress may increase. Therefore, in the current scenario, there is a need for developing newer and effective methods to study behavioural responses. Behavioural changes in a fish form an efficient index to measure any alterations in the environmental conditions (Sharma 2019).

Behavioural changes are one of the most sensitive indicators of potential toxic effects in fishes (Banaue et al. 2011). Based on the results obtained and data shown in the Table 7, it can be concluded that the TIE is toxic to the aquatic environment and fishes. Due to toxicity, morphology and behaviour of C.batrachus are altered and it exhibits hyperactivity with high effluent concentration.

Table 7: Behaviour of Clariasbatrachusto textile effluent during acute toxicity test.

\begin{tabular}{|c|c|c|c|c|c|}
\hline $\begin{array}{l}\text { Behavioural and morpholog- } \\
\text { ical response }\end{array}$ & $\begin{array}{l}0 \% \\
\text { Concentration (v/v) }\end{array}$ & $\begin{array}{l}10 \% \text { Concentration } \\
(\mathrm{v} / \mathrm{v})\end{array}$ & $\begin{array}{l}30 \% \text { Concentration } \\
(\mathrm{v} / \mathrm{v})\end{array}$ & $\begin{array}{l}50 \% \text { Concentration } \\
(\mathrm{v} / \mathrm{v})\end{array}$ & $\begin{array}{l}70 \% \text { Concentration } \\
(\mathrm{v} / \mathrm{v})\end{array}$ \\
\hline Mucus secretion & None & Mild & Moderate & Strong & Very strong \\
\hline Uncoordinated movement & None & Mild & Strong & Very strong & Very strong \\
\hline Restlessness & None & Mild & Moderate & Strong & Very Strong \\
\hline Tailfin movement & None & Mild & Moderate & Strong & Very Strong \\
\hline Loss of balance & None & None & Moderate & Strong & Very strong \\
\hline Surfacing & None & None & Moderate & Maximum & Maximum \\
\hline Loss of buoyancy & None & None & Mild & Moderate & Maximum \\
\hline Escaping tendency & None & None & Mild & Maximum & Maximum \\
\hline Hyperactivity & None & None & Mild & Moderate & Maximum \\
\hline Discolouration of skin & None & None & Mild & Moderate & Maximum \\
\hline
\end{tabular}




\section{Haematological Parameters}

Haematological analysis can provide valuable knowledge for monitoring the health and condition of both wild and culture fish.Haematological tests and analysis for serum constituents have shown useful information in the detection and diagnosis of metabolic disturbance and diseases in fishes (Jamalzadeh et al. 2009).

Bhanu et al. (2013) studied that due to the influence of toxic mill effluent the amount of RBC and $\mathrm{Hb}$ have been decreased in the blood of fish Bat the amount of WBC has been increased as an immunological defence to survive against the toxic substance in the effluent. Haematological parameters of the blood of fish such as $\mathrm{Hb} \%$, total WBC count, Differential count of WBC, and total RBC count after exposure of T. mossambica to $100 \%$ untreated and treated textile effluent for a period of 15 days showed different morphological changes. The morphological change of the blood cells was more prominent in the untreated sample than that of treated blood samples due to the high toxicity of untreated effluent (Deepika \& Noorjahan 2018).

Haematological changes in the blood due to Textile effluent in the freshwater fish, C.batrachus on different exposure periods is shown in Table 8.
Different haematological parameters were evaluated. $\mathrm{RBC}$, haemoglobin (Hb), packed cell volume (PCV), mean corpuscles haemoglobin concentration (MCHC) and mean corpuscles haemoglobin $(\mathrm{MCH})$ values exhibited significantly decreased (Table 8 and Figs. 6-11, 13) whereas total white blood corpuscles (WBC) and glucose level were gradually increased (Table 8 and Figs. 12 and 14) in treated fish when compared with controls (Table 8). The present study clearly indicates the toxic effects of these chemicals on haematological parameters of fish that are seen in Figs. 6-14.

\section{CONCLUSION}

The present study was carried out to evaluate the acute toxicity and behavioural responses in Clarias batrachus (Linnaeus) exposed to textile industrial effluent.The results clearly indicate that exposure of fishes to industrial based textile effluent resulted in increased mortality with increasing concentration of the effluent. In this study it is observed that textile effluent caused many behavioural and morphological alterations, which may result in severe physiological problems, ultimately leading to the death of fish.Most of the haematological parameters like RBC, Hb, PCV, MCV,

Table 8: Haematological changes in the blood due to Textile effluent in the freshwater fish, C.batrachus on different exposure periods.

\begin{tabular}{|lllllll|}
\hline S.No. & Blood parameter & Control & $24 \mathrm{hr}$ & $48 \mathrm{hrs}$ & $72 \mathrm{hrs}$ \\
\hline 1. & RBC $\left(1 \times 10^{6} \mathrm{~mm}^{3}\right)$ & $2.70 \pm 0.03$ & $2.65 \pm 0.08$ & $2.46 \pm 0.14$ & $2.35 \pm 0.06$ & $2.24 \pm 0.05$ \\
2. & WBC $\left(1 \times 10^{3} \mathrm{~mm}^{3}\right)$ & $5.90 \pm 0.12$ & $6.35 \pm 0.08$ & $6.58 \pm 0.16$ & $6.85 \pm 0.05$ & $7.10 \pm 0.16$ \\
3. & Haemoglobin $(\mathrm{gm} / \mathrm{dl})$ & $7.65 \pm 0.03$ & $6.90 \pm 0.05$ & $6.25 \pm 0.08$ & $5.90 \pm 0.12$ & $4.65 \pm 0.04$ \\
4. & Haematocrit $\%(\mathrm{PCV})$ & $24.2 \pm 0.14$ & $22.10 \pm 0.14$ & $20.15 \pm 0.14$ & $18.6 \pm 0.14$ & $15.8 \pm 0.14$ \\
5. & MCV $(\mathrm{fl})$ & $89.62 \pm 1.15$ & $83.58 \pm 1.35$ & $81.91 \pm 0.12$ & $79.14 \pm 0.08$ & $70.53 \pm 1.35$ \\
6. & MCH $(\mathrm{pg})$ & $28.33 \pm 1.06$ & $26.03 \pm 1.04$ & $25.40 \pm 0.07$ & $25.10 \pm 0.14$ & $20.25 \pm 1.10$ \\
7. & MCHC $(\mathrm{g} / \mathrm{dl})$ & $31.61 \pm 0.09$ & $31.15 \pm 1.11$ & $31.01 \pm 0.06$ & $31.71 \pm 0.09$ & $29.43 \pm 1.15$ \\
8. & Protein $\mathrm{g} / \mathrm{dl}$ & $7.90 \pm 1.12$ & $6.85 \pm 1.10$ & $6.43 \pm 0.54$ & $5.78 \pm 0.84$ & $4.70 \pm 0.08$ \\
9. & Glucose $\mathrm{mg} / \mathrm{mL}$ & $80.5 \pm 3.14$ & $82.7 \pm 2.54$ & $84.80 \pm 3.10$ & $85.35 \pm 1.24$ & $90.20 \pm 2.44$ \\
\hline
\end{tabular}

Values are mean \pm SE of 6 values; $p \quad 0.001$ Highly significant; $p \quad 0.01$ Significant; $p \quad 0.05$ Almost significant

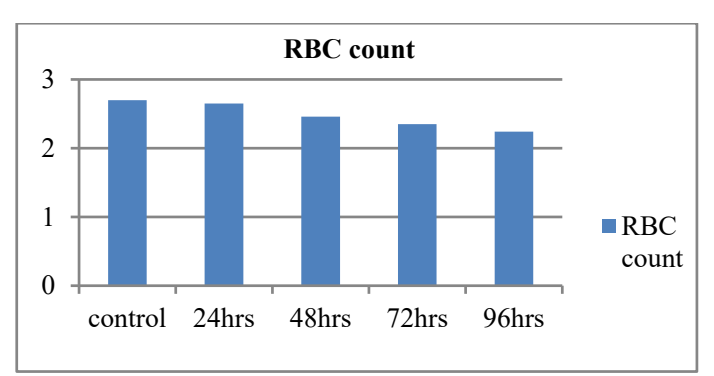

Fig. 6: Percentage changes in RBC of C.batrachus exposed to various concentrations of textile effluent.

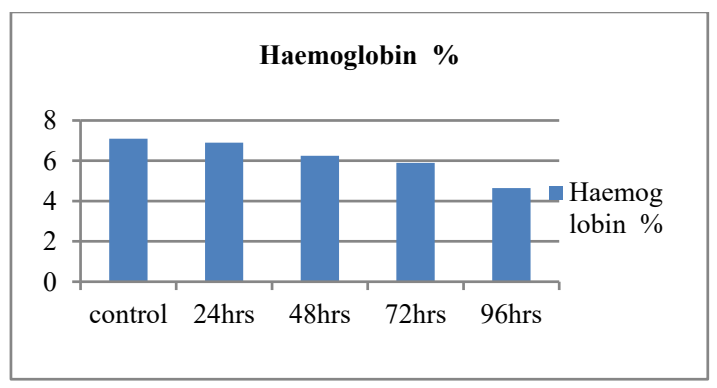

Fig. 7: Percentage changes in $\mathrm{Hb} \%$ of C.batrachus exposed to various concentrations of textile effluent. 


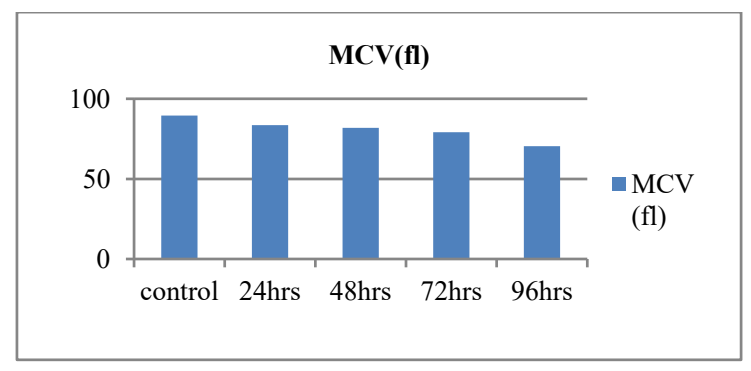

Fig. 8: Percentage changes in MCV of C.batrachus exposed to various concentrations of textile effluent.

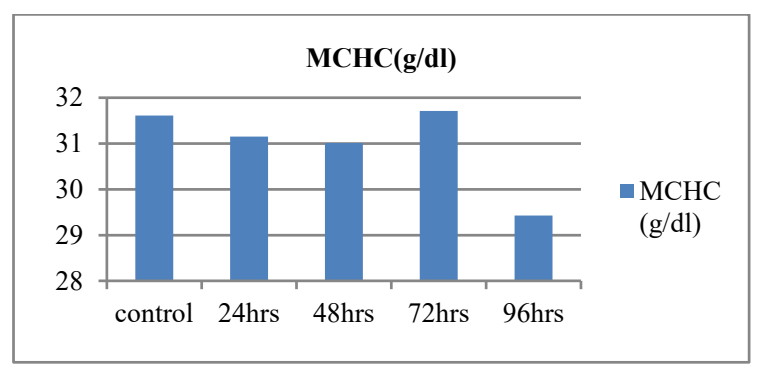

Fig. 10: Percentage changes in MCHC (g/dl) of C.batrachus exposed to various concentrations of textile effluent.

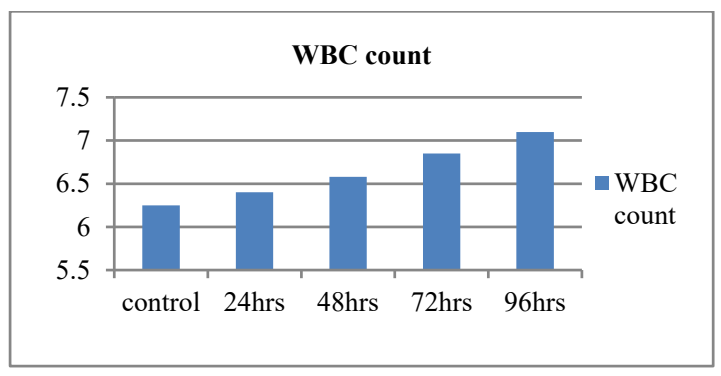

Fig. 12: Percentage changes in WBC of C.batrachus exposed to various concentrations of textile effluent.

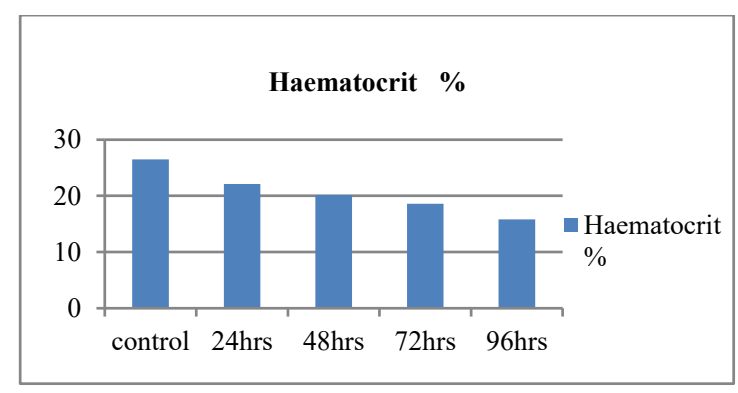

Fig. 9: Percentage changes in Haematocrit \% of C.batrachus exposed to various concentrations of textile effluent.

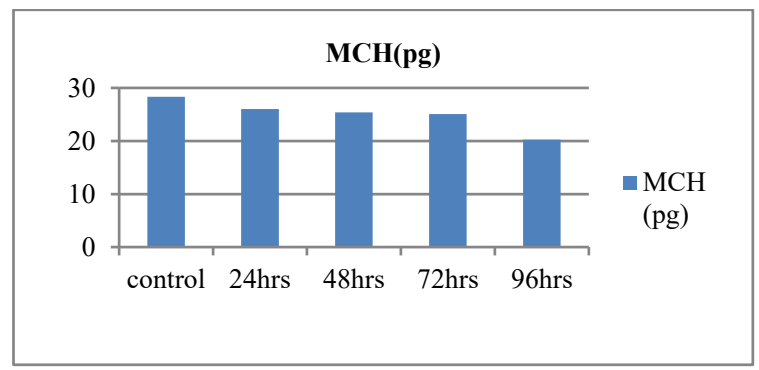

Fig. 11: Percentage changes in $\mathrm{MCH}(\mathrm{pg})$ of C.batrachus exposed to various concentrations of textile effluent.

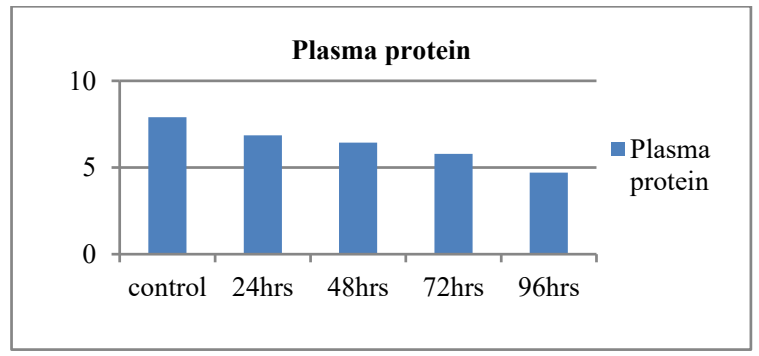

Fig. 13: Percentage changes in Plasma Protein (g/dl) of C.batrachus exposed to various concentrations of textile effluent.

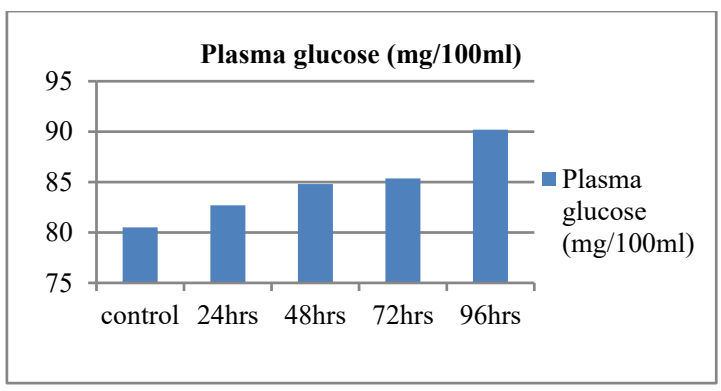

Fig. 14: Percentage changes in Plasma glucose level of C.batrachus exposed to various concentrations of textile effluent.

$\mathrm{MCH}, \mathrm{MCHCand}$ protein level were found to be increased while WBC and glucose level were decreased when fish was exposed to textile effluents in different time.In the present investigation, it can be concluded that industrial-based textile effluent of different textile industries of Pali city is highly toxic to freshwater fish C.batrachus. This study observed that CETP (common effluent treatment plants) of Pali city is not properly working and many textile mills discharging 
untreated effluents into Bandi River directly. It shows that textile effluent is highly polluted and treatment is necessary prior to discharge of wastewater in Bandi River of Pali city.

\section{ACKNOWLEDGMENT}

I acknowledge all authorities of Jai Narain Vyas University Jodhpur, Rajasthan (India) for the support and providing the necessary facility to complete this work. Also, I am grateful to my guide Prof. Anil Choudhary, my friends, colleagues and my wife for their constructive comments and suggestions.

\section{REFERENCES}

Adeyemo, O.K., Naigaga, I. and Alli, R.A. 2009. Effect of handling and transportation on haematology of african catfish (Clarias gariepinus). J Fish Sci. Com., 3: 333.

Agbon, A.O., Omoniyi, I.T. and Teko, A.A. 2002. Acute toxicity of tobacco (Nicotiana tobaccum) leaf dust on Oreochromis niloticus and haematological changes resulting from sub lethal exposure. Journal of Aquatic Sciences, 17(1): 5-8.

Amte, G.K. and Mhaskar, T.V. 2013. Impact of textile-dyeing industry effluent on some haematological parameters of freshwater fish Oreochromis mossambicus. Nature Environment and Pollution Technology, 1)12): 93-98.

Amutha, P. and Mahalingam, S. 1999. Effect of dairy effluent on body composition of Cyprinus carpio (Cyprinidae). J. Ecotoxicol. Environ. Monit., 9(1): 3-8.

APHA 2000. Standard Method for the Examination of Water and Wastewater. American Public Health Association, 19th edition, American Public Health Association, Washington, DC.

Arya, P.D., Joseph, M.L. and Mathew,A.2018. Determination of LC50 of lead acetate for a fish Oreochromis mossambicus (Peters). International Journal of Fisheries and Aquatic Studies, 6(6): 180-182.

Banaue, M., Sureda, A., Mirvaghefi, A.R. and Ahmadi, K. 2011. Effects of diazinon on biochemical parameters of blood in rainbow trout (Oncorhynchus mykiss). Pestic. Biochem. Physiol., 99 (1): 1e6.

Berardi, M., Hsissou, R., Khudhair, M., Mohammed Assouag, M., Cherkaoui, O., Bachiri, A.E. and Harfi, A. E. 2019. Textile finishing dyes and their impact on aquatic environs.Heliyon, 5: e02711.

Bhanu, A. Paratha and Deepak, M. 2013. The Influence of Textile Mill Effluent on Haematological Changes of Labeo rohita. International Journal of Innovative Research in Science, Engineering, and Technology, 8003-8001:(12)2.

Clauss,T.M., Dove, A.D. and Arnold, J.E. 2008. Hematologic disorders of fish. Vet. Clin. North Am. Exot. Anim. Pract., 11: 445-462.

Deepali and Gangwar, K.K. 2010. Metals concentration in textile and tannery effluents associated soils and groundwater, New York Science Journal, 3(4): 82-88.

Deepika, T. and Noorjahan, C. M. 2018. Impact of untreated and treated textile effluent on haematological parameters of freshwater fish, Tilapia mossambica. International Journal of Advanced Scientific Research and Management, 3 (6): 24-28.

Eaton, D.L. and Gilbert, S.G. 2008. Principles of toxicology. Casarett\&Doull's Toxicology: The Basic Science of Poisons, Eighth ed. McGraw-Hill Medical, New York, pp. 11e43.

Fafioye, O.O., Adeogun, O.A., Olayinka, E.A. and Ayoade, A.A. 2001. Effect of Sub-lethal concentrations of lead on growth of Clarias gariepinus. Nigerian Experimental Biology, 5(1): 61-68.
Farah, M.A., Ateeq, B., Ali, M.N., Sabir, R. and Ahmad, W. 2004. Studies on lethal concentrations and toxicity stress of some xenobiotics on aquatic organisms. Chemosphere, 55(2): 257e265.

Finney, DJ. 1971. Probit Analysis. Cambridge University Press, London.

Gupta, N. and Dua, A. 2010. Mercury induced behavioral alterations in Channa punctatus. Pollution Research, 29(4):721-723.

Hader, D.P. 2018. Ecotoxicological monitoring of wastewater. In: Häder, D.P. andErzinger, G.S. (eds) Bioassays, Advanced Methods and Applications. Elsevier Press, Cambridge, pp. 369-386.

Haniffa, M.A. and Arul, Selvan, S. 1991. Haematological and biochemical effects of textile mill effluent on the freshwater fish, Oreochromis mossambicus. Uttar Pradesh J. Zool., 11(1): 661-662.

Holkar, C.R., Jadhav, A.J., Pinjari,D.V., Mahamuni, N.M. and Pandit, A.B. 2016. A critical review of textile wastewater treatments: Possible approaches. J. Environ.Manag., 182: 351e366.

Hart, W.B., Doudoroff, P. and Greenbank, J. 1945. The evaluation of the toxicity of industrial wastes, chemical and other substances to freshwater fishes. Atlant. Refinding Co. (Phill).

Hossain, L., KantiSarker S. and Samad Khan,M. 2018. Evaluation of present and future wastewater impacts of textile dyeing industries in Bangladesh. Environ. Develop., 26: 23-33.

Jamalzadeh, H.R., Keyvan, A., Ghomi, M.R and Gherardi, F. 2009. Comparison of blood indices in healthy and fungal infected Caspian Salmon (Salmo trutta caspius). African Journal of Biotechnology, 8(2): 319- 322.

Makwana, S. 2020a.Impact assessment of anthropological activities on water quality of historical Gulab Sagar pond, Jodhpur, Rajasthan (India). International Journal for Research in Applied Science \& Engineering Technology, 8(10): 178-185

Makwana, S. 2020b. Effect of textile industrial effluents on water quality of Bandi River (Pali) Rajasthan, India. International Journal for Research in Applied Science \& Engineering Technology, 8(4): 21-28

Maruthi, Y. A. and Rao, S. R. 2001. Effect of sugar mill effluent on organic reserves of fish. Poll. Res., 20(2): 167-171.

Nagarajan, K. and Aruna, Devi, P. S. 2006. Histological changes in Indian freshwater major carp Labeo rohita due to distillery effluent. Nature Environ. Polln. Tech., 5: 1 -6.

Nagarajan, K. and Boopathy, Raja, A. 2004. Studies on the effects of dyeing effluent on certain physiological aspects of the freshwater fish Cath catla. J. Exp. Indian, 1(1): 101-104.

Nagarajan, K. and Ramesh, F. 2001. Influence of Sago effluent on certain physiological and histological aspects of the freshwater fish Catla catla. Proc. ENVIRO 2001. Nat Conf. Cont. Ind. Poll Environ.Degrad., 470475.

Nagarajan, K. and Shasikumar, R. 2002. Effect of sago effluent on selected physiological aspects of the freshwater fish Labeo rohita. J.Ecotoxicol. Environ. Monit., 12(3):233-238.

Nagarajan, K. and Suresh, K. 2005. Impact of treated sago effluent on the levels of acid phosphatase, alkaline phosphatase, and lactate dehydrogenase in Cirrhinus mrigala. J.Indust.Polln. Cont., 21(1): 115 -120.

Omoregie, E., Malachy, N.O., Ajino, I., Romanus, I. and Kazimierz, W. 2009. Effect of Single super-phosphate fertilizer on survival and respiratory dynamics of Oreochromis niloticus. Acta Ichthyological Et Piscatoria, 39(2): 103-110.

Rahman, M.Z., Hossain, Z., Mollagh, M.F.A. and Ahmed, G.U. 2002. Effect of Diazinon 60EC on Testudineus (C. punctatus and B. gonionotus). The ICLARM Quarterly, 25(2): 8-12.

Rand, G. M. and Petrocelli, S. R. (Eds.)1985. In: Fundamentals of Aquatic Toxicology Methods and Applications. Hemisphere Publishing Corporation, Washington, U.S.A., pp. 1 -28.

Sarvajith, M., Reddy, G., Kiran Kumar and Nancharaiah, Y.V. 2018. Textile dye decolorization and ammonium removal over nitrite in aerobic 
granular sludge sequencing batch reactors. J. Hazard Mater., 342: 536-543.

Shanthi, M. 2003. Effects Of Tannery Effluent On Certain Physiological And Histological Aspects Of The Freshwater Fish Catlacatla. M. Phil. Dissertation. Bharathiar University.

Satish and Sharma,K. C. 2008. Waste Water Management with Reference of Textile and Dyes Industries of Pali District. M. Phil. Thesis (Environmental Management), M.D.S. University, Ajmer.

Sharma, M. 2019. Behavioural responses in effect to chemical stress in fish: A review. International Journal of Fisheries and Aquatic Studies, 7(1): 01-05.

Soni, Rakesh and Verma, S.K. 2018. Acute toxicity and behavioural responses in Clarias batrachus (Linnaeus) exposed to herbicide pretilachlor. Heliyon, 4: e01090.

Sreelekshmy, S.G., Miranda, M.T.P. and Rajesh, B.R. 2016. Acute toxicity of industrial effluent on the marine catfish Arius nanga (Hamilton,
1822).International Journal of Fisheries and Aquatic Studies, 4(3): 215-219.

Srivastav, A.K. and and Roy, D. 2015. Effects of malachite green (Triarylmethane dye) and Pyceze (Bronopol) on the hematological parameters of a freshwater catfish Heteropneustes fossilis (Bloch). International Journal of Fisheries and Aquatic Studies, 2(6): 119-122.

Taiwo, O., Durotoye, Aderonke A., Adeyemi, David, O. Omole and OlumuyiwaOnakunle, Amimul Ahsan2018. Impact assessment of wastewater discharge from textile industry in Lagos, Nigeria. Cogent Engineering, 5: 1, DOI: 10.1080/23311916.2018.1531687.

Umar, M., Stephen, S.H., Abdullahi, M. and Garba, 2010. M. Dichlorvos concentrations in locally formulated pesticides (Ota-pia pia) utilized in Northeastern Nigeria. Scientific Research and Essay, 5(1): 049-054.

Yaseen, D.A. and Scholz, M. 2019.Textile dye wastewater characteristics and constituents of synthetic effluents: A critical review. Int. J. Environ. Sci. Technol., 16: 1193-1226 https://doi.org/10.1007/s13762-018-2130-z. 